\title{
Upregulated expression of brain enzymatic markers of arachidonic and docosahexaenoic acid metabolism in a rat model of the metabolic syndrome
}

\author{
Ameer Y Taha ${ }^{1 \dagger}$, Fei Gao ${ }^{1+}$, Epolia Ramadan ${ }^{1}$, Yewon Cheon ${ }^{1}$, Stanley I Rapoport ${ }^{1}$ and Hyung-Wook Kim ${ }^{1,2^{*}}$
}

\begin{abstract}
Background: In animal models, the metabolic syndrome elicits a cerebral response characterized by altered phospholipid and unesterified fatty acid concentrations and increases in pro-apoptotic inflammatory mediators that may cause synaptic loss and cognitive impairment. We hypothesized that these changes are associated with phospholipase (PLA 2 ) enzymes that regulate arachidonic (AA, 20:4n-6) and docosahexaenoic (DHA, 22:6n-6) acid metabolism, major polyunsaturated fatty acids in brain. Male Wistar rats were fed a control or high-sucrose diet for 8 weeks. Brains were assayed for markers of AA metabolism (calcium-dependent cytosolic CPLA IVA and cyclooxygenases), DHA metabolism (calcium-independent iPLA $\mathrm{A}_{2} \mathrm{VIA}$ and lipoxygenases), brain-derived neurotrophic factor (BDNF), and synaptic integrity (drebrin and synaptophysin). Lipid concentrations were measured in brains subjected to high-energy microwave fixation.
\end{abstract}

Results: The high-sucrose compared with control diet induced insulin resistance, and increased phosphorylated${ }_{C} P L A_{2}$ protein, $C P L A_{2}$ and $P L A_{2}$ activity and 12-lipoxygenase mRNA, but decreased BDNF mRNA and protein, and drebrin mRNA. The concentration of several $\mathrm{n}-6$ fatty acids in ethanolamine glycerophospholipids and lysophosphatidylcholine was increased, as was unesterified AA concentration. Eicosanoid concentrations (prostaglandin $\mathrm{E}_{2}$, thromboxane $\mathrm{B}_{2}$ and leukotriene $\mathrm{B}_{4}$ ) did not change.

Conclusion: These findings show upregulated brain AA and DHA metabolism and reduced BDNF and drebrin, but no changes in eicosanoids, in an animal model of the metabolic syndrome. These changes might contribute to altered synaptic plasticity and cognitive impairment in rats and humans with the metabolic syndrome.

Keywords: Arachidonic acid, Docosahexaenoic acid, BDNF, Brain, Polyunsaturated fatty acids (PUFA), Metabolic syndrome, Drebrin, Sucrose, Insulin resistance

\section{Background}

The metabolic syndrome is a clinical disorder characterized by obesity, hypertension, dyslipidemia, glucose intolerance and peripheral inflammation [1-3], and is a risk factor for cognitive decline and mood disorders [4-8]. In rodent models of the metabolic syndrome, behavioral abnormalities have been linked to cerebral

\footnotetext{
*Correspondence: peterkhw@gmail.com

${ }^{\dagger}$ Equal contributors

'Brain Physiology and Metabolism Section, National Institute on Aging, National Institutes of Health, Bethesda, MD 20892, USA

${ }^{2}$ Department of Environmental and Occupational Health Science, University of Washington, Box 3572341705 Pacific St, Seattle, WA 98195, USA
}

hypoglycemia [9] and increased cytokine production [10], and changes in brain lipid metabolism $[11,12]$.

The brain is highly enriched with the polyunsaturated fatty acids (PUFAs), arachidonic acid (AA, 20:4n-6) and docosahexaenoic acid (DHA, 22:6n-3) [13-15], which mostly are esterified in the stereospecifically numbered-2 position of membrane phospholipids. AA and DHA are essential for mediating neuroreceptor signaling, while excessive AA is released during neuroinflammation and excitotoxicity [16-19]. Stimulation of AA signaling by glutamatergic, serotonergic, cholinergic or dopaminergic neuroreceptors, among others, triggers AA release by

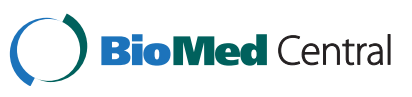


AA-selective $\mathrm{Ca}^{2+}$-dependent cytosolic phospholipase $\mathrm{A}_{2}$ (cPLA $\mathrm{C}_{2}$ IVA) (reviewed in [19]). Unesterified AA is a precursor of prostaglandins, thromboxanes, leukotrienes, and related compounds that have important roles in regulating the brain's neuroinflammatory response [1315,20-25]. Stimulation of DHA release from membrane phospholipid via DHA-selective calcium-independent $\mathrm{iPLA}_{2}$ type VIA is thought to be neuroprotective, and shows anti-inflammatory effects based on in vitro and in vivo studies [17,26-30]. Disturbed brain AA and DHA metabolism has been linked to a number of neurodegenerative diseases, including Alzheimer's disease and bipolar disorder [31-33], which are more common in individuals with the metabolic syndrome [4-8].

Brain lipid metabolism is altered in the metabolic syndrome. In a rat model of intracerebroventricular streptozotocin-induced brain insulin resistance and hypoglycemia, cerebral cortex concentrations of ethanolamine glycerophospholipid (EtnGpl) and phosphatidylserine (PtdSer) were decreased, while concentrations of unesterified palmitate, stearate and AA were increased, suggesting increased PLA $\mathrm{PL}_{2}$-mediated membrane degradation $[11,12]$. Brain phospholipid concentration was reported reduced in a genetic mouse model of diabetes [34]. An increased hippocampal malonaldehyde concentration, a marker of PUFA oxidative degradation, was reported in the hippocampus of genetically obese and hypertensive rats [35]. Taken together, these studies suggest an effect of the metabolic syndrome on the enzymes that regulate brain PUFA metabolism, such as AA-selective cPLA 2 IVA and iPLA $_{2}$ VIA, which prefers DHA but also can release AA [36,37].

Unesterified AA can be converted to pro-inflammatory and pro-apoptotic secondary mediators, such as prostaglandin E2 (PGE2), thromboxane B2 (TXB2) 82 and leukotriene B4 (LXB4), via cyclooxygenase-2 (COX-2) or 5, 12 and 15 lipoxygenase (LOX) [17,38]. These eicosanoids can cause synaptic-dendritic injury by reducing brain levels of trophic factors, such as brain-derived neurotrophic factor (BDNF) $[39,40]$. In this regard, studies reported decreased BDNF and synaptic loss [41-43] in association with cognitive impairment and behavioral changes, in animal models of the metabolic syndrome $[10,41,44]$. Although iPLA $_{2}$ VIA can regulate peripheral glucose-stimulated insulin secretion, apoptosis and mitochondrial fatty acid oxidation $[45,46]$, its involvement in modulating brain lipid metabolism in the metabolic syndrome is not known [38].

In view of the reported changes in brain concentrations of phospholipids and PUFAs, and of neuronal loss in animal models of the metabolic syndrome [41-43], we hypothesized correlated disturbances in brain $\mathrm{CPLA}_{2}$ IVA and iPLA $_{2}$ VIA expression, fatty acid concentrations, synaptic loss, BDNF, and $\mathrm{PGE}_{2}, \mathrm{TXB}_{2}$ and $\mathrm{LXB}_{4}$ concentrations. Such changes have been reported in animal models of neuroinflammation [47-49].

To test this hypothesis, we induced early-stage metabolic syndrome by feeding rats a high-sucrose diet for 8 weeks. In this model, feeding a high-sucrose diet induces time-dependent changes in insulin-resistance and in other markers of the metabolic syndrome after 8 weeks [50], without causing diabetic pathology, fatty liver or weight gain [50-52], which may independently alter brain lipid metabolism [53]. Insulin resistance can be induced in this model without changing the fat composition of the diet, thereby eliminating confounding effects of diet on brain fatty acid composition [53]. In sucrose and control diet fed rats maintained for 8 weeks, we examined brain 1) expression of enzymes involved in AA and DHA metabolism (i.e., mRNA, protein and / or activity of cPLA 2 , iPLA COX-1, COX-2 and 5-, 12- and 15-LOX); 2) concentrations of $\mathrm{PGE}_{2}, \mathrm{TXB}_{2}$ and $\left.\mathrm{LXB}_{4} ; 3\right)$ mRNA levels of glialfibrillary acidic protein (GFAP) and tumor-necrosis factor- $\alpha$ (TNF- $\alpha)$, because of reported changes in these inflammatory markers in animal models of the metabolic syndrome [10]; 4) expression of BDNF, and of synaptophysin and drebrin as markers of synapto-dendritic injury [54]; and 5) esterified fatty acid concentrations in phospholipid subclasses, as well as unesterified fatty acids and lysophosphatidylcholine (lysoPC), as markers of phospholipid degradation. These measurements were performed to test whether phospholipase-mediated phospholipid breakdown occurs in this dietary rat model of the metabolic syndrome, in association with neuroinflammation and synapto-dendritic injury. These pathways are physiologically related because cytokine-induced inflammation, if present in the metabolic syndrome, can alter the expression AA or DHA-selective $\mathrm{PLA}_{2}$ 's and their downstream metabolites (e.g. eicosanoids) that modulate synapto-dendritic integrity and BDNF expression (reviewed in [55]).

\section{Results}

\section{Weight gain and food intake}

Figure 1 shows body weight (1-A) and food intake (1-B) over the 8-week course of the study. Two-way repeated measures analysis of variance revealed a significant main effect of time on weight and food intake, both of which increased. No significant effect of diet or interaction between diet and time was seen. Consistent with the lack of difference in body weight, weights of brain, liver, adipose tissue, heart, kidneys and testes, collected at the time of sacrifice, did not differ significantly between the two groups (data not shown, $\mathrm{p}>0.05$ by unpaired $t$-test).

\section{Oral glucose tolerance test}

Rats fed the high-sucrose diet showed evidence of impaired glucose metabolism, measured by an oral glucose 
A. Body weight over time in rats fed a control or highsucrose diet

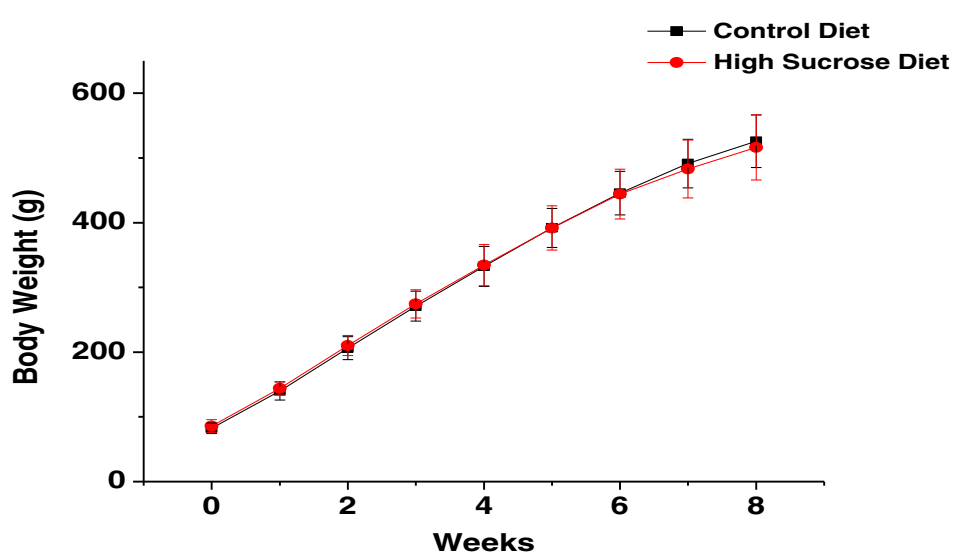

B. Food intake over time in rats fed a control or highsucrose diet

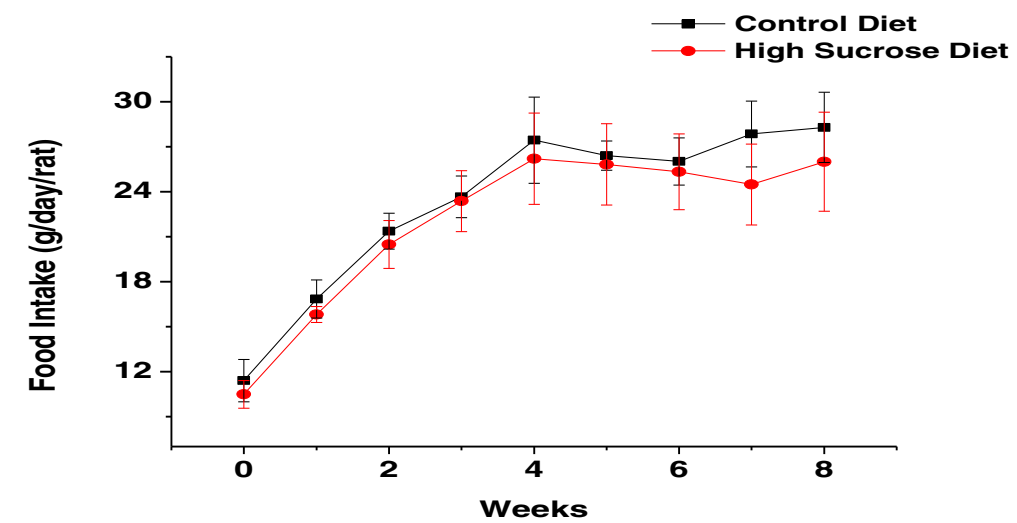

Figure 1 (A) Body weight and (B) food intake over time in rats fed a control or high- sucrose diet. Data are means \pm SD $(n=6)$. Two-way repeated measures analysis of variance revealed a significant effect of time only on body weight gain and food intake.

tolerance test at 4 and 8 weeks. Two-way repeated measures analysis of variance showed a significant main effect of diet and time on whole blood glucose concentrations at 4 (Figure 2A) and 8 weeks (Figure 2B). At 4 and 8 weeks, fasting whole blood glucose concentration was similar between the two groups at baseline. The glucose concentration was increased after an oral preload of glucose $(5 \mathrm{~g} / \mathrm{kg})$ and remained higher than baseline values by the end of the $2 \mathrm{~h}$ test. The rise in blood glucose concentration was significantly higher for the high-sucrose compared to control rats, suggesting reduced glucose tolerance in the sucrose- group.

\section{ß-hydroxybutyrate in whole blood}

Fasting ß-hydroxybutyrate concentration in whole blood, a marker of ketosis, was measured at 4 and 8 weeks, before starting the oral glucose tolerance test (Table 1). There was a significant effect of time on fasting ß-hydroxybutyrate concentration, but no effect of treatment or an interaction between time and diet. ß-hydroxybutyrate concentrations were significantly reduced for both dietary groups at 8 weeks compared to 4 weeks $(\mathrm{p}<0.05)$.

\section{Plasma insulin, glucose and triglyceride concentrations}

Rats on the high-sucrose diet showed insulin resistance and hypertriglyceridemia at 8 but not 4 weeks (Table 1 ). There was a significant interaction between time and diet $(\mathrm{p}<0.05)$ for fasting plasma, insulin, and triglyceride concentrations, and the homeostasis model assessment (HOMA) insulin-resistance index, calculated as previously described [56]. There was a significant main effect of diet on plasma glucose and triglyceride concentrations, and on the HOMA index. Time was a significant factor affecting glucose, insulin and triglyceride concentrations, and the HOMA index. Compared to controls, rats fed the high-sucrose diet had significantly higher plasma concentrations of glucose and triglycerides and HOMA index at 8 weeks. 


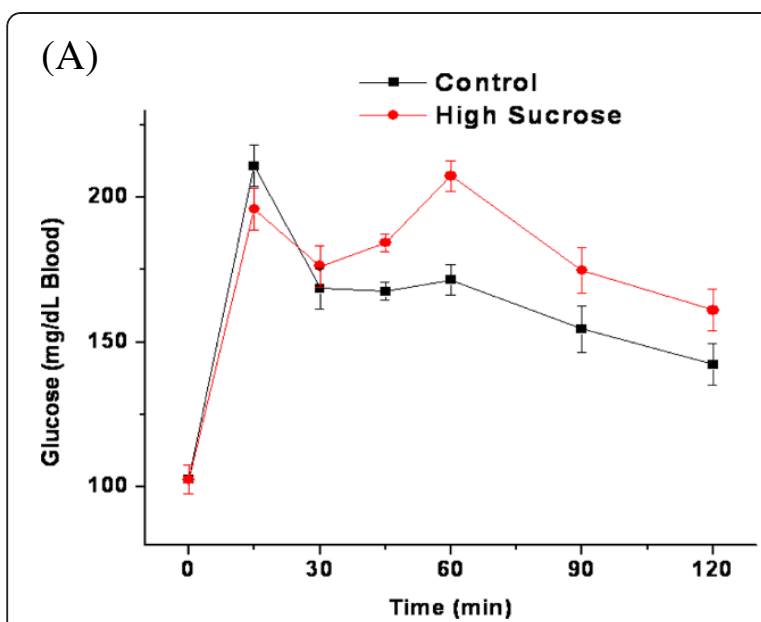

(B)

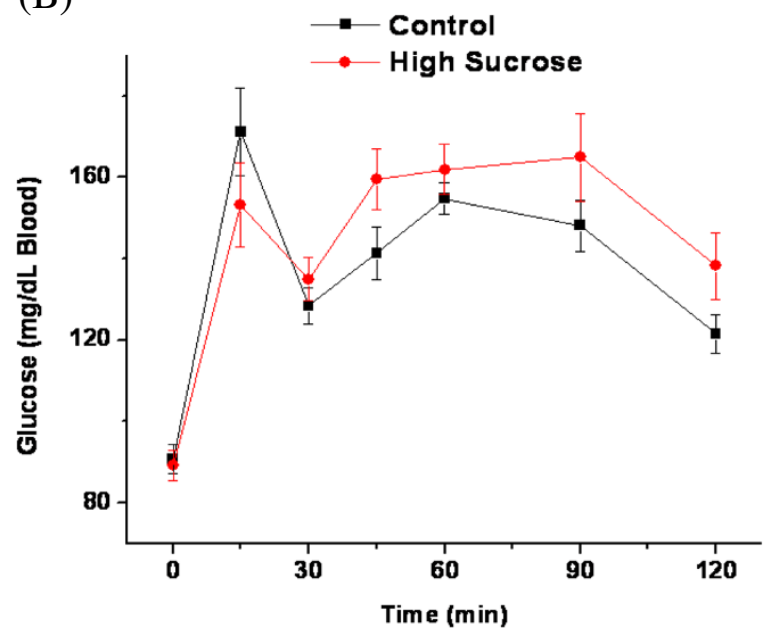

Figure $\mathbf{2}$ Oral glucose tolerance test in rats fed a control or high-sucrose diet. Blood glucose concentrations were measured by a glucometer after a $10 \mathrm{~h}$ fast at 0 and 15, 30, 34, 60, 90 and 120 min following gavage with $5 \mathrm{~g} / \mathrm{kg}$ of an oral glucose preload at $(\mathbf{A}) 4$ weeks and (B) 8 weeks of treatment. Two-way repeated measures analysis of variance showed a significant main effect of diet and time on blood glucose concentrations at 4 and 8 weeks.

\section{$\mathrm{CPLA}_{2}$ mRNA and protein}

mRNA and protein levels of brain CPLA $_{2}$ IVA did not differ significantly between rats fed the high sucrose and the control diet for 8 weeks (Figure $3 \mathrm{~A}$ and $3 \mathrm{~B}$ ). The protein level of phosphorylated-cPLA 2 (phospho$\mathrm{cPLA}_{2}$ ), which represents the active form of $\mathrm{cPLA}_{2}$ $[57,58]$, was increased significantly in the high-sucrose group compared to the control group (Figure $3 \mathrm{C}$ ). Consistent with the increase, in phosphorylated-cPLA 2 activity of $\mathrm{CPLA}_{2}$ was significantly increased in the high-sucrose group (Figure $3 \mathrm{D}$ ).

\section{iPLA $_{2}$ and sPLA 2 mRNA, protein and activity}

iPLA $_{2}$ VIA and sPLA 2 IIA mRNA and protein did not differ significantly between rats fed the high sucrose and the control diet for 8 weeks (Figure 4A, B, D, E). The activity of $\mathrm{iPLA}_{2}$ was significantly increased in the highsucrose group (Figure $4 \mathrm{C}$ ), whereas $\mathrm{sPLA}_{2}$ activity did not differ significantly between the groups (Figure 4F).

\section{$\mathrm{PGE}_{2}, \mathrm{TXB}_{2}$ and $\mathrm{LTB}_{4}$ concentrations}

There was no significant difference in $\mathrm{PGE}_{2}, \mathrm{LTB}_{4}$ or $\mathrm{TXB}_{2}$ concentration between the two groups (Figure 5A-C).

\section{GFAP, TNF-a, COX and LOX mRNA}

There was no significant change in GFAP or TNF- $\alpha$ mRNA (data not shown). mRNA levels of COX-1 and COX-2 also were not affected by the high-sucrose diet (data not shown), nor was 5- or 15-LOX mRNA changed significantly. Brain 12-LOX mRNA was increased significantly (control, $1.00 \pm 0.07$; high-sucrose, $1.22 \pm$ $0.05 ; \mathrm{p}<0.05$ by unpaired t-test).

mRNA and protein levels of BDNF and synaptic markers Compared with control diet, the high-sucrose diet decreased significantly mean protein and mRNA levels of BDNF (Figure 6A and B). mRNA and protein levels of the pre-synaptic marker synaptophysin did not differ significantly between the groups (Figure 6C and D). There was a significant decrease in mRNA of the post-synaptic

Table 1 Plasma glucose, insulin and triglyceride concentrations, calculated HOMA index and whole blood B-hydroxybutyrate concentrations at 4 and 8 weeks of feeding control or high-sucrose diet

\begin{tabular}{|c|c|c|c|c|c|c|c|}
\hline \multirow[b]{2}{*}{ Parameter } & \multicolumn{2}{|l|}{4 weeks } & \multicolumn{2}{|l|}{8 weeks } & \multirow[b]{2}{*}{ Time } & \multirow[b]{2}{*}{ Diet } & \multirow[b]{2}{*}{ Time $\mathbf{x}$ Die } \\
\hline & Control & High-sucrose & Control & High-sucrose & & & \\
\hline Glucose (mmol/L) & $4.0 \pm 0.41$ & $4.4 \pm 0.1$ & $4.1 \pm 1.0$ & $6.0 \pm 1.8^{* * *}$ & $<0.05$ & $<0.01$ & \\
\hline Insulin (ng/ml) & $0.6 \pm 0.4$ & $0.3 \pm 0.1$ & $0.7 \pm 0.3$ & $1.8 \pm 0.9^{* *}$ & $<0.001$ & & $<0.05$ \\
\hline HOMA1 index & $2.3 \pm 1.91$ & $1.4 \pm 0.41$ & $4.1 \pm 4.1$ & $10.5 \pm 4.8^{* *}$ & $<0.001$ & $<0.05$ & $<0.05$ \\
\hline Triglycerides (mg/ml) & $0.9 \pm 0.2$ & $0.7 \pm 0.2$ & $0.7 \pm 0.3$ & $1.5 \pm 0.5^{* *}$ & $<0.05$ & $<0.05$ & $<0.01$ \\
\hline $\bar{\beta}$-hydroxybutyrate (mmol/L) & $0.9 \pm 0.2$ & $0.9 \pm 0.2$ & $0.6 \pm 0.2$ & $0.7 \pm 0.11$ & $<0.05$ & & \\
\hline
\end{tabular}

Values are means $\pm S D(n=8)^{1} n=7$ due to insufficient sample. ${ }^{1} n=7$ due to insufficient sample. Data were analyzed by two-way repeated measures ANOVA, followed by a one-way ANOVA and Bonferroni's post-hoc test comparing high-sucrose versus controls at 4 and 8 weeks. ${ }^{* *} p<0.01 ;{ }^{* * *} p<0.001$ indicates significant difference compared to 8-week control mean. 


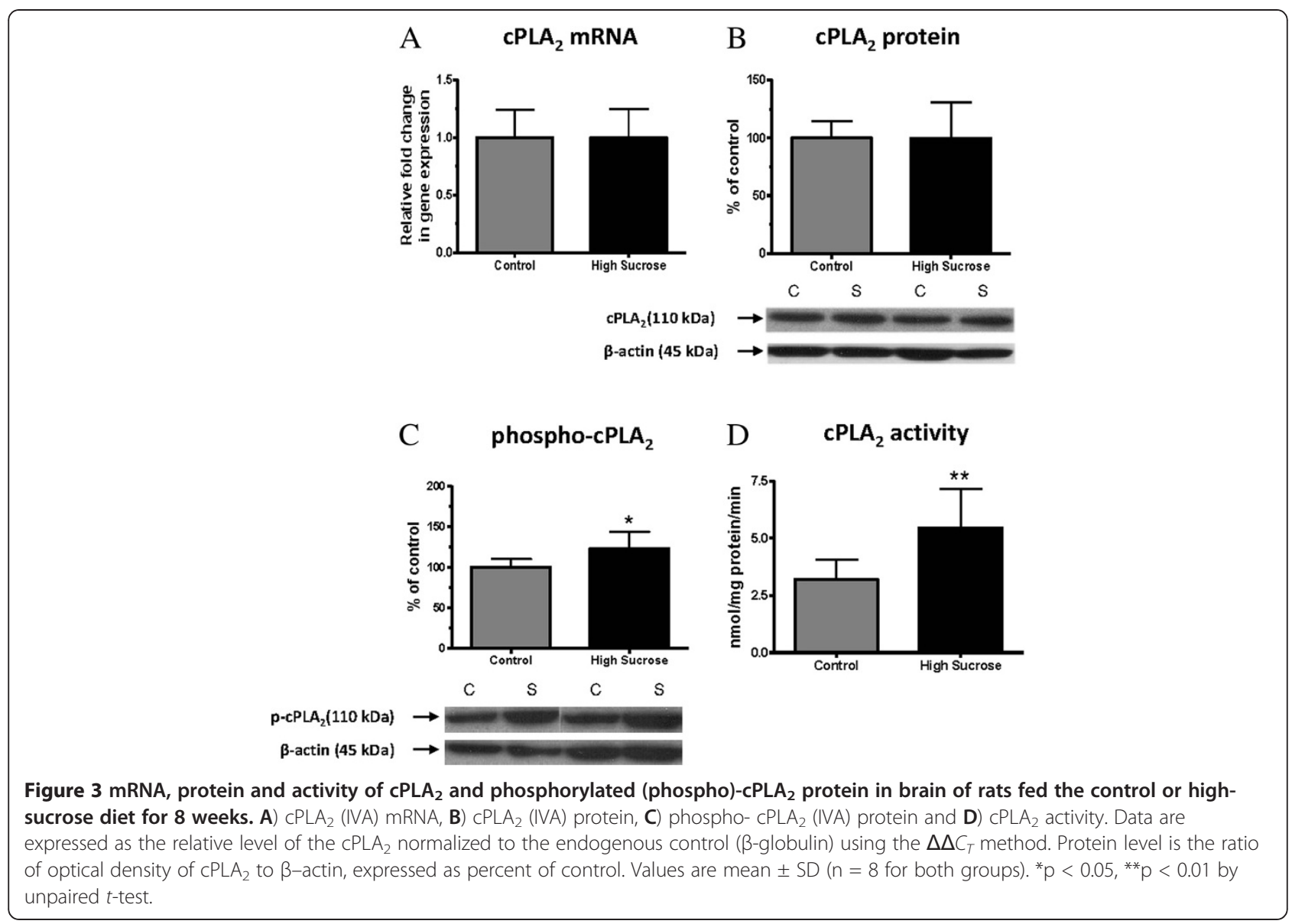

dendritic spine marker [54], drebrin (Figure 6E), but no significant change in its protein level (Figure 6F).

\section{Brain fatty acid concentrations}

There were few significant differences in brain esterified fatty concentrations (data not shown): a 12-16\% increase in AA $(6262 \pm 459 \mathrm{nmol} / \mathrm{g}$ brain wet wt, control, $7234 \pm$ $468 \mathrm{nmol} / \mathrm{g}$ wet wt, sucrose) and adrenate (22:4n-6; $3321 \pm 275 \mathrm{nmol} / \mathrm{g}$ wet wt, control, $3738 \pm 158 \mathrm{nmol} / \mathrm{g}$ wet wt, sucrose) in EtnGpl, and a 29\% increase in dihomo- $\gamma$-linolenic acid (20:3n-6; $7 \pm 1 \mathrm{nmol} / \mathrm{g}$ wt wet, control, $9 \pm 1 \mathrm{nmol} / \mathrm{g}$ wt wet, sucrose) in lysoPC in rats on the high-sucrose compared to control diet ( $\mathrm{p}<0.05)$. For unesterified fatty acids, one sample from the highsucrose group was excluded from the analysis because its unesterified AA concentration was 3-fold higher than the mean, which suggests ischemia caused by incomplete microwave-fixation [59]. The unesterified AA concentration was significantly increased (by 20\%) in the highsucrose diet group, whereas the DHA concentration did not differ significantly from control (Figure 7). Other unesterified fatty acid concentrations also did not differ between the groups (data not shown).

\section{Discussion}

Rats fed the high-sucrose diet (60\% sucrose) for 8 weeks did not show obesity or increased food intake, but developed hypertriglyceridemia and insulin resistance, two components of the metabolic syndrome, as reported [50-52]. At 8 weeks, some brain enzymatic markers of AA and DHA metabolism were increased significantly in the high sucrose compared with control diet group (e.g., protein level of phospho-cPLA $A_{2}$, activities of cPLA and $\mathrm{iPLA}_{2}$ ) as was the esterified $\mathrm{AA}$ concentration in EtnGpl and unesterified AA concentration. BDNF mRNA and protein and drebrin mRNA were reduced, but synaptophysin mRNA and protein were not altered. Feeding the high-sucrose diet for 8 weeks did not change $\mathrm{PGE}_{2}$, $\mathrm{TXB}_{2}$ or $\mathrm{LTB}_{4}$ concentration significantly. Because the 8 -week high-sucrose feeding paradigm represents earlystage metabolic syndrome in the absence of pathological diabetes or obesity [50,51], these findings demonstrate changes in brain PUFA metabolizing enzymes and composition in association with reduced BDNF and drebrin mRNA at an early disease stage.

The upregulation of brain $\mathrm{CPLA}_{2}$ and $\mathrm{iPLA}_{2}$ enzyme activities (Figure 3 and 4 ) in the high-sucrose fed rats suggests an increase in brain AA and DHA metabolism. 


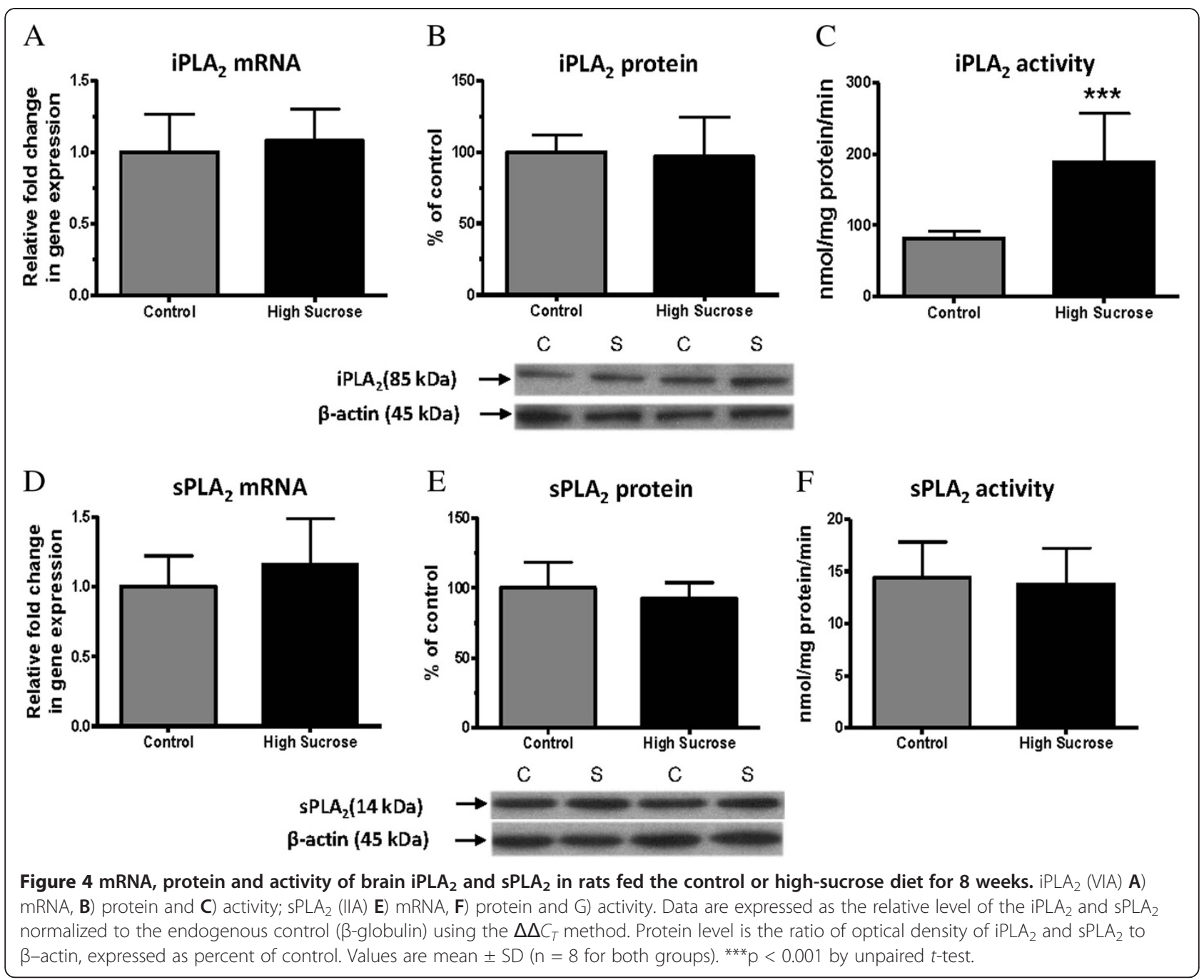

In this regard, disturbed saturated brain fatty acid metabolism has been reported in humans and rats with the metabolic syndrome [60,61]. A positron emission tomography study demonstrated increased brain uptake of $\left[{ }^{11} \mathrm{C}\right]$ palmitate and $\left[{ }^{18} \mathrm{~F}\right]$ fluoro-6-thia-heptadecanoic acid in patients with the metabolic syndrome [60]. Hypothalamic concentrations of long-chain saturated acyl-CoAs were increased in a high-fat diet animal model of the metabolic syndrome, also indicating increased metabolism of longchain saturated fatty acids [61]. Taken together, the results suggest non-specific upregulation in brain fatty acid metabolism, including PUFAs, associated with the metabolic syndrome. Upregulated AA or DHA metabolism could be directly confirmed in this animal model, using
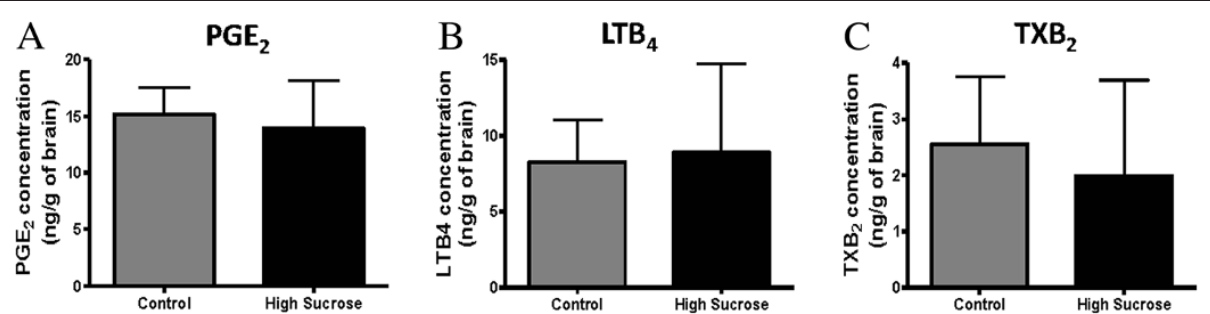

Figure 5 Levels of $A) P_{G E}, B$ ) $L T B_{4}$, and C) $T X B_{2}$ in brain of rats fed a control or high-sucrose diet for 8 weeks. $P G E_{2}$, $L T B_{4}$, and $T X B_{2}$ were extracted according to the method of Radin [82] and analyzed using a polyclonal enzyme-linked immunosorbent assay. Values are mean $\pm \mathrm{SD}$ ( $\mathrm{n}=8$ for both groups). ${ }^{*} \mathrm{p}<0.05$ by unpaired $t$-test. 


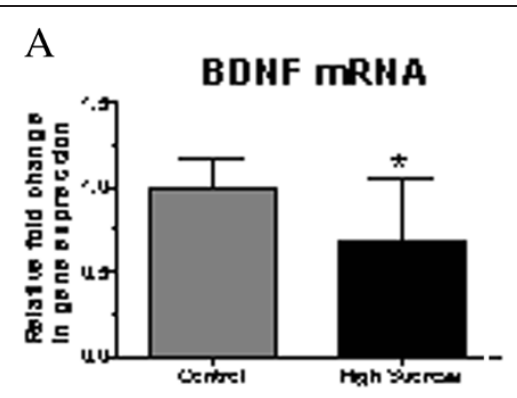

C
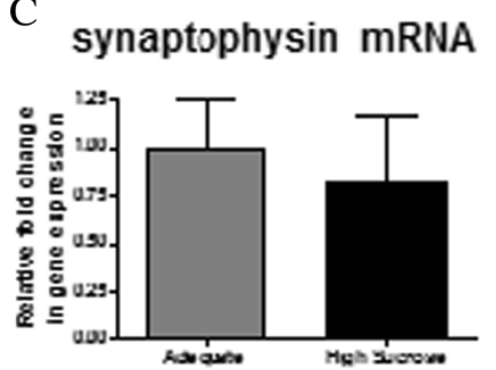

\section{B}

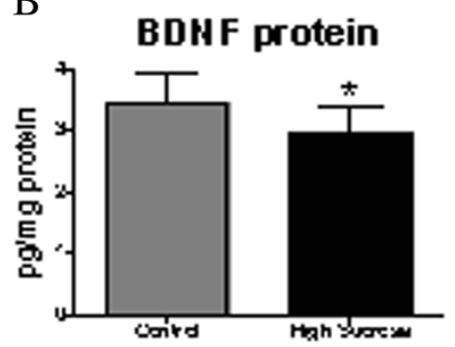

D

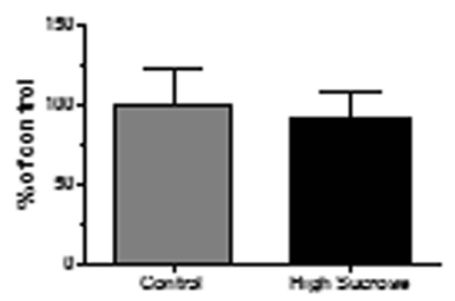

$c s$ c $s$

Sfrnap (34kDa) $\rightarrow$

$\beta-\operatorname{actin}(46 \mathrm{kDa}) \rightarrow$

E drebrin mRNA

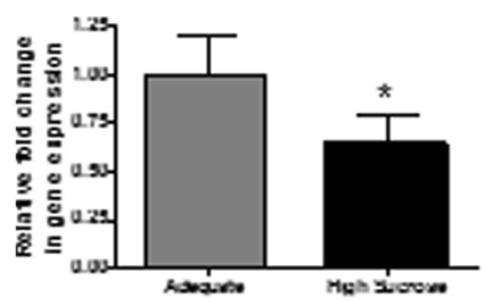

$\mathrm{F}$

\section{drebrin protein}

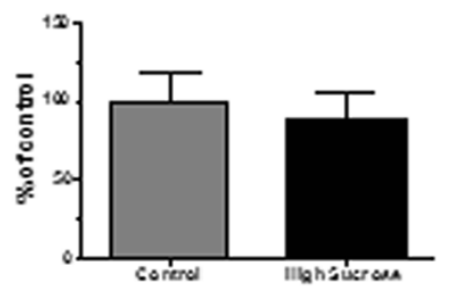

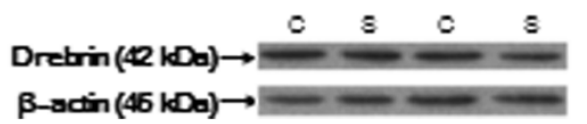

Figure 6 mRNA and protein levels of BDNF and synaptic markers in brain of rats fed a control or high-sucrose diet for 8 weeks. A) BDNF mRNA, B) BDNF protein, C) synaptophysin mRNA, D) synaptophysin protein, E) drebrin mRNA and $\mathbf{F}$ ) drebrin protein. Data are expressed as relative level of BDNF, synaptophysin and drebrin normalized to endogenous control ( $\beta$-globulin) using the $\Delta \Delta C_{T}$ method. The BDNF protein level was measured by an ELISA kit. The protein level is the ratio of optical density of synaptophysin or drebrin to $\beta$-actin, expressed as percent of control. Values are mean \pm SD ( $n=8$ for both groups). ${ }^{*} p<0.05$ by unpaired $t$-test.

quantitative autoradiography to image fatty acid uptake following radiotracer injection, or can be examined in humans using positron emission tomography [31,38,62].

The released fatty acids may be alternative energy substrates to glucose for brain metabolism, due to cerebral hypoglycemia caused by insulin-resistance. This is consistent with evidence of increased brain activity of carnitine palmitoyltransferase (which regulates fatty acid entry from the acyl-CoA pool into mitochondria for later $\beta$-oxidation) in an animal model of the metabolic syndrome [34]. ${ }^{14} \mathrm{C}$-palmitate conversion to ${ }^{14} \mathrm{C}-\mathrm{CO}_{2}$ also was increased in mitochondrial brain extracts of diabetic $(\mathrm{db} / \mathrm{db})$ mice [34].

Brain cPLA $_{2}$ activity and phospho-cPLA 2 protein, a marker of activated $\mathrm{CPLA}_{2}[57,58]$, were increased in the high-sucrose fed rats in the absence of changes in $\mathrm{CPLA}_{2}$ mRNA or protein, suggesting post-translational modification and upregulated brain AA metabolism, consistent with the increased unesterified AA concentration (Figure 7). Increased activation of $\mathrm{cPLA}_{2}$ may reflect excitotoxicity associated with increased influx of extracellular calcium into the cell via ionotropic glutamatergic 


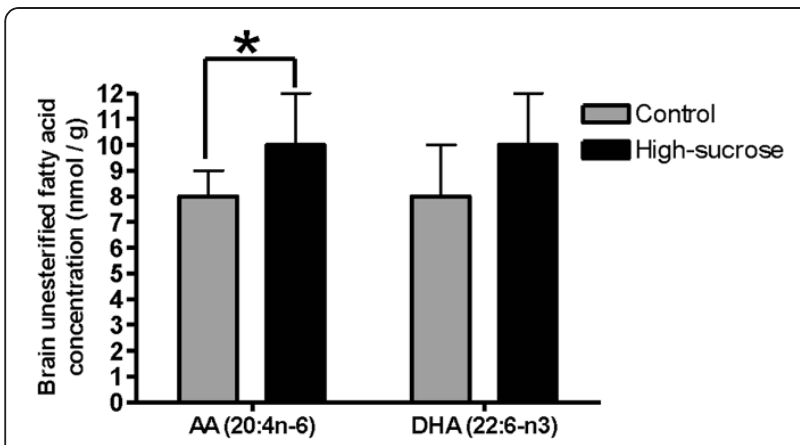

Figure 7 Brain concentrations of unesterified AA and DHA in rats fed a control or high-sucrose diet for $\mathbf{8}$ weeks. Values are mean \pm SD ( $n=8$ for both groups). ${ }^{*} p<0.05$ by unpaired $t$-test.

receptors [63]. Since cPLA $A_{2}$ also is functionally coupled via G-proteins to dopaminergic, serotonergic and muscarinic neuroreceptors [19], an increase in its activity suggests disturbed G-protein neuroreceptor signaling in the metabolic syndrome [64]. Cytokine receptor activation may also initiate $\mathrm{CPLA}_{2}$ activation [65], although our findings do not suggest an increase in cytokine expression in rats fed the high-sucrose diet.

iPLA $_{2}$ is insensitive to extracellular calcium influx into the neuron $[24,63]$, but can be activated by intracellular calcium (at $\mathrm{mM}$ concentrations) released from the endoplasmic reticulum by the calcium-releasing ryanodine receptor [66]. Mobilization of intracellular calcium stores can be mediated by increased intracellular unesterified AA levels, which was reported to activate the ryanodine receptor in vitro [66]. This is in agreement with the finding that the unesterified AA concentration was increased in the high-sucrose diet rats (Figure 7). Likely, this increase in AA concentration occurred intracellularly, since sPLA, which releases AA extracellularly, was not changed significantly (Figure 4 ).

Concentrations of pro-inflammatory eicosanoids $\left(\mathrm{PGE}_{2}\right.$, $\mathrm{TXB}_{2}$ and $\mathrm{LTB}_{4}$ ) did not differ between the groups (Figure 5). It is possible, however, that changes in eicosanoids or cytokines [65] occurred in specific brain regions such as the hippocampus, as reported in genetically diabetic mice, or that longer administration of the high-sucrose diet sufficient to initiate diabetes would increase whole brain cytokine levels [10]. However, consistent with the lack of significant changes in the three eicosanoids, we did not find significant changes in mRNA levels for COX-1, COX-2, 5- or 15-LOX in the high-sucrose fed rats, nor in TNF- $\alpha$ or GFAP mRNA, suggesting the absence of neuroinflammation, since transcription of these molecular markers occurs within transcriptional circuits related to neuroinflammation [67-69].

Whole brain BDNF mRNA and protein levels were reduced in the high-sucrose group (Figure 6), in agreement with previous studies that showed reduced BDNF levels in animal models of the metabolic syndrome with behavioral impairment $[10,41,42]$. Reduced BDNF expression was not mediated by pro-inflammatory eicosanoids, which were not changed. One possibility is that the increased unesterified AA concentration in the high-sucrose animals decreased BDNF and induced apoptosis, as reported in cultured spinal cord neurons [70]. Reduced BDNF expression in the sucrose-fed rats may have promoted dendritic injury, which was indirectly suggested by the reduction in drebrin mRNA (Figure 6), or have altered the cellular dynamics and structural organization of dendritic spines in the absence of changes in drebrin protein. Changes in dendritic morphology and dynamics could be the topic of future studies. Additionally, more severe changes in synaptic structure are likely to occur with prolonged exposure to the high-sucrose diet, since the 8-week feeding paradigm causes only early-stage metabolic syndrome without obesity, diabetes or liver damage [41,44,52].

Contrary to reports using other models involving central insulin resistance $[12,34,42]$, we did not find evidence of phospholipid degradation in the brain, since phospholipid mass, derived by the summation of total fatty acids within each phospholipid class, did not differ between the dietary groups (Table 1). Also, lysoPC, a marker of phospholipid breakdown, was not changed (Table 1). The changes in phospholipid fatty acid concentrations were relatively minor, and were significant only for a few $n-6$ PUFAs in EtnGpl (AA and 22:4n-6) and in lysoPC $(20: 3 n-6)$.

\section{Conclusion}

In summary, brain enzymatic markers of AA and DHA metabolism were increased in a rat model of early-stage metabolic syndrome, in association with reduced BDNF mRNA and protein, and drebrin mRNA. Increases in ${ }_{\text {cPLA }}$ and iPLA 2 activities support the notion of phospholipase-mediated neurodegeneration [11,12,34,35]. The decreases in BDNF and drebrin suggest increased susceptibility to synapto-dendritic injury.

In the future, an upregulation in brain AA and DHA metabolism associated with the metabolic syndrome might be imaged in humans with positron-emitting tomography using radiolabeled AA or DHA [31,62], as biomarkers of disease progression [4,5,71]. Therapeutic strategies aimed at downregulating brain PUFA metabolism, such as the administration of carnitine palmitoyltransferase inhibitors [72,73] or $\mathrm{PLA}_{2}$ inhibitors (e.g. the mood stabilizers, lithium and carbamazepine), might be effective in slowing the progression of brain lipid abnormalities identified in this study, the associated changes in synaptic loss and possibly, cognitive dysfunction in the metabolic syndrome. 


\section{Methods \\ Animals}

The protocol was approved by the Animal Care and Use Committee of the Eunice Kennedy Schriver National Institute of Child Health and Human Development and followed the National Institutes of Health Guide for the Care and Use of Laboratory Animals (NIH Publication No. 80-23). Post-weaning male Wistar rats purchased from Charles River Laboratories (Portage, MI, USA) were housed in an animal facility with regulated temperature, humidity, and a $12 \mathrm{~h}$ light/12 h dark cycle. After weaning, pups were divided randomly into control diet $(n=14)$ and high sucrose diet $(n=14)$ groups. The metabolic syndrome was confirmed in 8 out of 14 rats per dietary group, by measuring body weight and food intake weekly, and measuring tail vein plasma glucose, insulin and triglyceride concentrations at 4 and 8 weeks. An oral glucose tolerance test was also administered at 4 and 8 weeks to the same rats ( $\mathrm{n}=8$ rats per group) as described below. After 8 weeks on a chosen diet, half the rats from each dietary group ( $n=8$ per group) were asphyxiated by $\mathrm{CO}_{2}$ inhalation, decapitated and their brains excised rapidly, frozen in 2-methylbutane with dry ice at $-50^{\circ} \mathrm{C}$, and stored at $-80^{\circ} \mathrm{C}$ until use. Brain, testes, adipose tissue, liver and heart were collected, weighed, frozen in 2-methylbutane and stored at $-80^{\circ} \mathrm{C}$.

Brain lipids and eicosanoids $\left(\mathrm{PGE}_{2}, \mathrm{TXB}_{2}\right.$ and $\left.\mathrm{LTB}_{4}\right)$ were measured in the remaining animals ( $n=6$ per roup) that had undergone a catheter implantation surgery followed by a $2-h$ infusion protocol of $\left[D^{5}\right]-\alpha$-linolenic acid $\left(17,17,18,18,18-\mathrm{D}^{5}\right)$ and $\left[\mathrm{U}^{13} \mathrm{C}\right]$-linoleic acid (Spectra Stable Isotopes, Columbia, MD, USA) to assess liver PUFA kinetics (Taha et al., unpublished). After the $2 \mathrm{~h}$ infusion, the rats were lightly anesthetized with sodium pentobarbital $(50 \mathrm{mg} / \mathrm{kg}$; Abbott Laboratories, Chicago, IL, USA) and subjected to head-focused microwave irradiation stop brain lipid metabolism (5.5 kW, 4.8 s; Cober Electronics, Stamford, CT, USA) [74]. Brains were excised, separated sagittally into two halves and stored at $-80^{\circ} \mathrm{C}$ until analyzed.

\section{Diets}

The control and high sucrose diets were obtained from Dyets Inc. (Bethlehem, PA, USA), and were based on the AIN-93G formulation [75]. The diets were isocaloric and identical in macronutrient and micronutrient composition, but differed in carbohydrate composition. The control diet contained cornstarch $(150 \mathrm{~g} / \mathrm{kg}$ diet $)$, sucrose $(100 \mathrm{~g} / \mathrm{kg})$, dextrose $(200 \mathrm{~g} / \mathrm{Kg})$ and maltose dextrin $(150 \mathrm{~g} / \mathrm{kg})$. The high-sucrose diet contained sucrose $(600 \mathrm{~g} / \mathrm{kg})$ as the sole carbohydrate source (Table 2). The fatty acid composition of the diets was identical, and contained $7.8 \mu \mathrm{mol} / \mathrm{g} \alpha$-LNA $(4.6 \%$ total fatty acid), which is the minimum level of $\alpha$-LNA for $n-3$ PUFA
Table 2 Composition of control diet and high-sucrose diet

\begin{tabular}{lll}
\hline Ingredients & Control diet & High-sucrose diet \\
\hline Protein & (gram/Kg diet) & \\
\hline Casein & 200 & 200 \\
\hline Cornstarch & 200 & 200 \\
\hline Sucrose & 150 & 0 \\
\hline Dextrose & 100 & 600 \\
\hline Maltose Dextrin & 200 & 0 \\
\hline Hydrogenated coconut oil & 150 & 0 \\
\hline Safflower oil & 60 & 60 \\
\hline Flaxseed oil & 32.3 & 32.3 \\
\hline Cellulose & 77 & 77 \\
\hline Salts & 50 & 50 \\
\hline Vitamins & 35 & 35 \\
\hline L-Cystine & 10 & 10 \\
\hline Choline bitartrate & 3 & 3 \\
\hline t-Butylhydroquinone & 2.5 & 2.5 \\
\hline
\end{tabular}

adequacy in rodents, $40 \mu \mathrm{mol} / \mathrm{g}$ LA (25\% total fatty acid), $110 \mu \mathrm{mol} / \mathrm{g}$ saturated fatty acid $(68.5 \%$ of total $)$, and $10 \mu \mathrm{mol} / \mathrm{g}$ monounsaturated fatty acid [76]. Other PUFAs, including AA and DHA were absent.

\section{Plasma glucose, insulin, and triglyceride measurement}

Blood was collected at 4 and 8 weeks from the tail vein after an overnight $10 \mathrm{~h}$ fast ( $\mathrm{n}=8$ per group), and plasma glucose, insulin and triglyceride concentrations were determined with a glucose oxidase kit (Sigma), an Insulin ELISA kit (Alpco Diagnostics, Salem, NH, USA) and a triglyceride kit (Sigma), respectively. The insulin and glucose concentrations were used to calculate the 'homeostasis model assessment' (HOMA) index of insulin resistance, by multiplying glucose $(\mathrm{mmol} / \mathrm{L})$ and insulin (mU/L) concentrations, and dividing by 22.5 [56].

\section{Oral glucose tolerance test and $\beta$-hydroxybutyrate} measurement

An oral glucose tolerance test $[77,78]$ was performed at 4 and 8 weeks post-weaning, 2 days after the tail vein blood withdrawals described above. For this test, blood was obtained by tail-prick using a sharp needle. After an overnight $10 \mathrm{~h}$ fast, baseline blood glucose and $ß$-hydroxybutyrate concentrations were assayed using a commercial glucometer (LifeScan, Milpitas, CA, USA). The rats then were gavaged with $0.375 \mathrm{~g}$ glucose $/ \mathrm{ml}$ (5 g glucose $/ \mathrm{kg}$ body wt), and blood glucose concentrations were determined 15, 30, 45, 60, 90, and $120 \mathrm{~min}$ later. 


\section{Brain total fatty acid concentration}

Brain total lipids were extracted by the Folch method [79]. An aliquot of the total lipid extract was methylated with $1 \% \mathrm{H}_{2} \mathrm{SO}_{4}$-methanol for $3 \mathrm{~h}$ at $70^{\circ} \mathrm{C}$, or separated into phospholipid subfractions with thin layer chromatography (TLC) using heptane / diethyl ether / acetic acid $(60: 40: 3 \mathrm{v} / \mathrm{v} / \mathrm{v})$ as a solvent. Unesterified fatty acids were separated with TLC using chloroform / methanol / acetic acid / water $(60: 50: 1: 4 \mathrm{v} / \mathrm{v} / \mathrm{v} / \mathrm{v})$. Prior to methylation, di-17:0 PC was added as an internal standard to total lipids and phospholipid subfractions. Unesterified 17:0 was added as an internal standard to unesterified fatty acids. Samples were methylated with $1 \% \mathrm{H}_{2} \mathrm{SO}_{4}$-methanol for $3 \mathrm{~h}$ at $70^{\circ} \mathrm{C}$. The resulting fatty acid methyl esters were extracted and analyzed using a gas chromatograph (6890N, Agilent Technologies, Palo Alto, CA, USA) equipped with an SP-2330 fused silica capillary column (30 $\mathrm{m} \times 0.25 \mathrm{~mm}$ i.d., $0.25 \mu \mathrm{m}$ film thickness) (Supelco, Bellefonte, PA, USA) and a flame ionization detector. Concentrations were calculated by proportional comparison of peak areas to the area of the 17:0 internal standard.

\section{Preparation of cytoplasmic and membrane extracts}

Cytoplasmic and membrane extracts for Western blots were prepared using a compartmental protein extraction kit according to the manufacturer's instructions (Millipore, Temecula, CA, USA). Protein concentrations of cytoplasmic and membrane extracts were determined using Bio-Rad Protein Reagent (Bio-Rad, Hercules, CA, USA).

\section{Western Blot Analysis}

Proteins from cytoplasmic $(50 \mu \mathrm{g})$ and membrane extracts $(50 \mu \mathrm{g})$ were separated on 4-20\% SDS-polyacrylamide gels (PAGE) (Bio-Rad). Following SDS-PAGE, the proteins were electrophoretically transferred to a nitrocellulose membrane. Protein blots were incubated overnight at $4^{\circ} \mathrm{C}$ in Tris-buffered saline (TBS) buffer, containing 5\% nonfat dried milk and $0.1 \%$ Tween-20, with specific primary antibodies (1:1000 dilution) for the group IVA cPLA $_{2}$, phospho-cPLA 2 , group IIA secretory sPLA, group VIA iPLA 2 (Santa Cruz Biotech, Santa Cruz, CA), drebrin, synaptophysin (Cell Signaling, Beverly, MA), and $\beta$-actin (Sigma-Aldrich, St. Louis, MO). Protein blots were incubated with appropriate HRP-conjugated secondary antibodies (Cell Signaling) and visualized using a chemiluminescence reaction (Amersham, Piscataway, NJ) on X-ray film (XAR-5, Kodak, Rochester, NY). Optical densities of immunoblot bands were measured using Alpha Innotech Software (Alpha Innotech, San Leandro, $\mathrm{CA})$ and were normalized to $\beta$-actin to correct for unequal loading. All experiments were carried out three times with 8 independent samples per group. Values are expressed as percent of control.

\section{BDNF protein levels}

BDNF protein levels were measured in brain cytosolic extracts using an ELISA kit. according to the manufacturer's instructions (Millipore, Temecula, CA). Values are expressed in $\mathrm{pmol} / \mathrm{mg}$ protein.

\section{Total RNA isolation and real time RT-PCR}

Total RNA was prepared from brain using commercial kits (RNeasy Lipid Tissue Kit; Qiagen, Valencia, CA). cDNA was prepared from total RNA using a highcapacity cDNA Archive Kit (Applied Biosystems, Foster City, CA). mRNA levels were measured by real time quantitative RT-PCR, using the ABI PRISM 7000 sequence detection system (Applied Biosystems). For specific primers and probes for target genes, TaqMan ${ }^{R}$ gene expression assays, purchased from Applied Biosystems, consisted of a 20X mix of unlabeled PCR primers and Taqman minor groove binder probe (FAM dye-labeled). The fold change in gene expression was determined using the $\Delta \Delta C_{T}$ method [80]. Data are expressed as the relative level of the target gene in the high-sucrose animals normalized to the endogenous control ( $\beta$-globulin) and relative to the control rats (calibrator). All experiments were carried out in duplicates with 8 independent samples per group.

\section{Phospholipase $A_{2}$ activities \\ Sample preparation}

Brain tissue was homogenized with 3 vol of homogenization buffer (10 mM HEPES, pH 7.5, containing $1 \mathrm{mM}$ EDTA, $0.34 \mu \mathrm{M}$ sucrose and protease inhibitor cocktail (Roche, Indianapolis, IN)), using a glass homogenizer. The homogenized sample was centrifuged at $100,000 \mathrm{~g}$ for $1 \mathrm{~h}$ at $4^{\circ} \mathrm{C}$, and the supernatant was used for all $\mathrm{PLA}_{2}$ enzyme activity analyses. Supernatants were kept at $-80^{\circ} \mathrm{C}$ until use. The protein concentration was analyzed by the Bradford assay (Bio-Rad) [81].

\section{Enzyme assay with radioisotope method}

The final incubation volume was $0.5 \mathrm{ml}$. To measure ${ }_{\text {cPLA }}$ activity, the cytosolic fraction $(0.3 \mathrm{mg}$ protein in one assay, $\sim 50 \mu \mathrm{l}$ ) was mixed with $100 \mathrm{mM}$ HEPES, pH 7.5 containing $80 \mu \mathrm{M} \mathrm{Ca}^{2+}, 2 \mathrm{mM}$ dithiothreitol and $0.1 \mathrm{mg} / \mathrm{ml}$ fatty acid-free bovine serum albumin (total volume $=450 \mu \mathrm{l}$ ). The enzyme reaction was started by adding fifty $\mu \mathrm{l}$ of substrate solution containing $100 \mu \mathrm{M}$ 1-palmitoyl-2-arachidonoyl-sn-glycerol3-phosphorylcholine and phosphatidylinositol 4,5-bisphosphate (97:3) (Avanti Polar Lipids, Alabaster, AL, USA), and approximately $100,000 \mathrm{dpm}$ of 1-palmitoyl-2-[1- $\left.{ }^{14} \mathrm{C}\right]$ arachidonoyl-sn-glycerol-3-phosphorylcholine (specific activity of $60 \mathrm{mCi} / \mathrm{mmol}$, PerkinElmer, Boston, MA) in 400 $\mu \mathrm{M}$ triton $\mathrm{X}-100$ per assay, To measure iPLA $\mathrm{A}_{2}$ activity, the cytosolic fraction $(0.3 \mathrm{mg}$ protein in one assay) was mixed with $100 \mathrm{mM}$ HEPES, $\mathrm{pH} 7.5,5 \mathrm{mM}$ 
EDTA, $2 \mathrm{mM}$ dithiothreitol, and $1 \mathrm{mM}$ ATP (total volume $=450 \mu \mathrm{l})$. Fifty $\mu \mathrm{l}$ substrate mixture of $100 \mu \mathrm{M}$ 1-palmitoyl-2-palmitoyl-sn-glycerol-3-phosphorylcholine containing approximately 100,000 dpm of 1-palmitoyl-2$\left[1-{ }^{14} \mathrm{C}\right]$ palmitoyl-sn-glycerol-3-phosphorylcholine (specific activity of $53 \mathrm{mCi} / \mathrm{mmol}$, Buckinghamshire, UK) in $400 \mu \mathrm{M}$ Triton $\mathrm{X}-100$ was added to start the enzyme reaction.

\section{Substrate preparation for radioisotope method}

Substrates for the $\mathrm{iPLA}_{2}$ and $\mathrm{CPLA}_{2}$ activity analyses described above were prepared daily. Appropriate amounts of cold and radiolabeled phospholipids were added to an appropriate amount of Triton X-100, and the mixture was dried with nitrogen gas. Water was added to the residues to give a $10 \mathrm{x}$ lipid mixture (1 $\mathrm{mM}$ phospholipid, $1,000,000 \mathrm{dpm}$, and $4 \mathrm{mM}$ Triton $\mathrm{X}-100)$, which was mixed vigorously.

\section{Enzyme assay}

The cytosolic fraction ( $0.3 \mathrm{mg}$ in one assay) was mixed with the assay mixture (total volume of $450 \mu \mathrm{l}$ ), and $50 \mu \mathrm{l}$ substrate mixture was added to start the enzyme reaction. The reaction mixture was incubated for $30 \mathrm{~min}$ at $40^{\circ} \mathrm{C}$, and then $2.5 \mathrm{ml}$ of Dole reagent (2-propanol, heptane: $0.5 \mathrm{M} \mathrm{H}_{2} \mathrm{SO}_{4}, 400: 100: 20$, vol/vol/vol) was added to stop the reaction. One and a half $\mathrm{ml}$ of heptane and $1.5 \mathrm{ml} \mathrm{H}_{2} \mathrm{O}$ were added to the mixture, followed by vortexing and centrifugation at $3000 \mathrm{rpm}$ for 5 minutes. The upper phase (about $2 \mathrm{ml}$ ) was transferred to a tube containing $200 \mathrm{mg}$ of silicic acid (200-400 mesh), followed by vortexing and centrifugation. The supernatant $(1.5 \mathrm{ml})$ was transferred to a scintillation vial, and scintillation cocktail was added (Ready Safe ${ }^{\mathrm{TM}}$ plus $1 \%$ glacial acetic acid). Radioactivity of the released unesterified fatty acid from the phospholipid substrate was counted on a liquid scintillation counter (2200CA, TRI-CARB ${ }^{\circledR}$, Packard Instruments, Meriden, CT, USA). iPLA ${ }_{2}$ and ${ }_{\text {CPLA }}$ activities were expressed as the release rate of fatty acid from phospholipids.

\section{sPLA $A_{2}$ activity}

sPLA $_{2}$ activity was measured using an appropriate assay kit (Cayman, Ann Arbor, MI, USA), according to the manufacturer's instructions.

\section{$\mathrm{PGE}_{2}, \mathrm{TXB}_{2}$, and $\mathrm{LTB}_{4}$ concentration}

$\mathrm{PGE}_{2}, \mathrm{TXB}_{2}$, and $\mathrm{LTB}_{4}$ were extracted according to the method of Radin [82]. A portion of the extract was dried under nitrogen and assayed for $\mathrm{PGE}_{2}, \mathrm{TXB}_{2}$, and $\mathrm{LTB}_{4}$ using a polyclonal enzyme-linked immunosorbent assay according to the manufacturer's instructions (Oxford Biomedical Research, Oxford, MI)

\section{Data and statistics}

Data are presented as means \pm SD $(n=8$ for each group). A two-way repeated measured analysis of variance (ANOVA) was used to test for effects of time and treatment on body weight, food intake, and insulin, glucose, $\beta$-hydroxybutyrate and triglyceride concentrations, and the response to an oral glucose preload performed at 4 and 8 weeks. An unpaired Student's $t$-test was used to compare means, taking $\mathrm{p}<0.05$ as the cut off for statistical significance.

\section{Abbreviations}

AA: arachidonic acid; ANOVA: analysis of variance; BDNF: brain derived neurotrophic factor; $\mathrm{CPLA}$ : cytosolic phospholipase $\mathrm{A}_{2}$ :

DHA: docosahexaenoic acid; EtnGpl: ethanolamine glycerophospholipids; HOMA: homeostasis model assessment; iPLA 2 : calcium-independent PLA

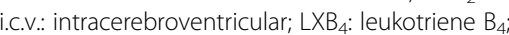
IysoPC: lysophosphatidylcholine; PAGE: polyacrylamide gels;

$\mathrm{PGE}_{2}$ : prostaglandin $\mathrm{E}_{2}$; PtdSer: phosphatidylserine; $\mathrm{SLA}_{2}$ : secretory PLA $\mathrm{A}_{2}$; $\mathrm{TXB}_{2}$ : thromboxane $\mathrm{B}_{2}$

\section{Competing interests}

The authors declare that they have no competing interests.

\section{Authors' contributions}

AYT, FG and SIR conceived and designed the study. AYT and FG carried out the animal experiments. HWK, AYT, YC, FG and IR were involved in the analysis. AYT, HWK and SIR were involved in writing and editing the manuscript. All authors read and approved the final manuscript.

\section{Acknowledgements}

This research was supported entirely by the Intramural Research Program of the National Institute on Aging, $\mathrm{NIH}$

Received: 17 July 2012 Accepted: 5 October 2012

Published: 30 October 2012

\section{References}

1. Alberti KG, Zimmet $P$, Shaw J: The metabolic syndrome-a new worldwide definition. Lancet 2005, 366(9491):1059-1062.

2. Eckel RH, Grundy SM, Zimmet PZ: The metabolic syndrome. Lancet 2005, 365(9468):1415-1428.

3. Zimmet PZ, Alberti KG, Shaw JE: Mainstreaming the metabolic syndrome: a definitive definition. Med J Aust 2005, 183(4):175-176.

4. Dunbar JA, Reddy P, Davis-Lameloise N, Philpot B, Laatikainen T, Kilkkinen A Bunker SJ, Best JD, Vartiainen E, Kai Lo S, et al: Depression: an important comorbidity with metabolic syndrome in a general population. Diabetes Care 2008, 31(12):2368-2373.

5. Fagiolini A, Frank E, Scott JA, Turkin S, Kupfer DJ: Metabolic syndrome in bipolar disorder: findings from the Bipolar Disorder Center for Pennsylvanians. Bipolar Disord 2005, 7(5):424-430.

6. Segura B, Jurado MA, Freixenet N, Albuin C, Muniesa J, Junque C: Mental slowness and executive dysfunctions in patients with metabolic syndrome. Neurosci Lett 2009, 462(1):49-53.

7. van den Berg E, Biessels GJ, de Craen AJ, Gussekloo J, Westendorp RG: The metabolic syndrome is associated with decelerated cognitive decline in the oldest old. Neurology 2007, 69(10):979-985.

8. Vanhanen M, Koivisto K, Moilanen L, Helkala EL, Hanninen T, Soininen $H_{\text {, }}$ Kervinen K, Kesaniemi YA, Laakso M, Kuusisto J: Association of metabolic syndrome with Alzheimer disease: a population-based study. Neurology 2006, 67(5):843-847.

9. Winocur G, Greenwood CE, Piroli GG, Grillo CA, Reznikov LR, Reagan LP, McEwen BS: Memory impairment in obese Zucker rats: an investigation of cognitive function in an animal model of insulin resistance and obesity. Behav Neurosci 2005, 119(5):1389-1395.

10. Dinel AL, Andre C, Aubert A, Ferreira G, Laye S, Castanon N: Cognitive and emotional alterations are related to hippocampal inflammation in a mouse model of metabolic syndrome. PLoS One 2011, 6(9):e24325. 
11. Muller D, Nitsch RM, Wurtman RJ, Hoyer S: Streptozotocin increases free fatty acids and decreases phospholipids in rat brain. J Neural Transm 1998, 105(10-12):1271-1281.

12. Plaschke K, Muller D, Hoyer S: Insulin-resistant brain state (IRBS) changes membrane composition of fatty acids in temporal and entorhinal brain cortices of rats: relevance to sporadic Alzheimer's disease? J Neural Transm 2010, 117(12):1419-1422.

13. Holman RT: Nutritional and functional requirements for essential fatty acids. Prog Clin Biol Res 1986, 222:211-228.

14. Innis SM: Essential fatty acids in infant nutrition: lessons and limitations from animal studies in relation to studies on infant fatty acid requirements. Am J Clin Nutr 2000, 71(1 Suppl):238S-244S.

15. Uauy R, Hoffman DR, Peirano P, Birch DG, Birch EE: Essential fatty acids in visual and brain development. Lipids 2001, 36(9):885-895.

16. Sun AY, Cheng Y, Sun GY: Kainic acid-induced excitotoxicity in neurons and glial cells. Prog Brain Res 1992, 94:271-280.

17. Rosenberger TA, Villacreses NE, Hovda JT, Bosetti F, Weerasinghe G, Wine RN, Harry GJ, Rapoport SI: Rat brain arachidonic acid metabolism is increased by a 6-day intracerebral ventricular infusion of bacterial lipopolysaccharide. J Neurochem 2004, 88(5):1168-1178.

18. Chang YC, Kim HW, Rapoport SI, Rao JS: Chronic NMDA administration increases neuroinflammatory markers in rat frontal cortex: cross-talk between excitotoxicity and neuroinflammation. Neurochem Res 2008, 33(11):2318-2323

19. Basselin M, Ramadan E, Rapoport SI: Imaging brain signal transduction and metabolism via arachidonic and docosahexaenoic acid in animals and humans. Brain Res Bull 2012, 87(2-3):154-171.

20. Burke JE, Dennis EA: Phospholipase A2 structure/function, mechanism, and signaling. J Lipid Res 2009, 50(Suppl):S237-S242.

21. Clark JD, Lin LL, Kriz RW, Ramesha CS, Sultzman LA, Lin AY, Milona N, Knopf JL: A novel arachidonic acid-selective cytosolic PLA2 contains a $\mathrm{Ca}(2+)$-dependent translocation domain with homology to PKC and GAP. Cell 1991, 65(6):1043-1051.

22. Farooqui AA, Ong WY, Horrocks LA: Inhibitors of brain phospholipase A2 activity: their neuropharmacological effects and therapeutic importance for the treatment of neurologic disorders. Pharmacol Rev 2006, 58(3):591-620

23. Green JT, Orr SK, Bazinet RP: The emerging role of group VI calciumindependent phospholipase A2 in releasing docosahexaenoic acid from brain phospholipids. J Lipid Res 2008, 49(5):939-944.

24. Strokin M, Sergeeva M, Reiser G: Docosahexaenoic acid and arachidonic acid release in rat brain astrocytes is mediated by two separate isoforms of phospholipase A2 and is differently regulated by cyclic AMP and Ca2 +. Br J Pharmacol 2003, 139(5):1014-1022.

25. Yang HC, Mosior M, Johnson CA, Chen Y, Dennis EA: Group-specific assays that distinguish between the four major types of mammalian phospholipase A2. Anal Biochem 1999, 269(2):278-288.

26. Bazan NG: Neuroprotectin D1 (NPD1): a DHA-derived mediator that protects brain and retina against cell injury-induced oxidative stress. Brain Pathol 2005, 15(2):159-166.

27. Marcheselli VL, Hong S, Lukiw WJ, Tian XH, Gronert K, Musto A, Hardy M, Gimenez JM, Chiang N, Serhan CN, et al: Novel docosanoids inhibit brain ischemia-reperfusion-mediated leukocyte infiltration and proinflammatory gene expression. J Biol Chem 2003, 278(44):43807-43817.

28. Rapoport SI: Arachidonic acid and the brain. J Nutr 2008, 138(12):2515-2520.

29. Serhan CN: Novel eicosanoid and docosanoid mediators: resolvins, docosatrienes, and neuroprotectins. Curr Opin Clin Nutr Metab Care 2005, 8(2):115-121.

30. Serhan CN, Oliw E: Unorthodox routes to prostanoid formation: new twists in cyclooxygenase-initiated pathways. J Clin Invest 2001, 107(12):1481-1489.

31. Esposito G, Giovacchini G, Liow JS, Bhattacharjee AK, Greenstein D, Schapiro M, Hallett M, Herscovitch P, Eckelman WC, Carson RE, et al: Imaging neuroinflammation in Alzheimer's disease with radiolabeled arachidonic acid and PET. J Nucl Med 2008, 49(9):1414-1421.

32. Kim HW, Rapoport SI, Rao JS: Altered expression of apoptotic factors and synaptic markers in postmortem brain from bipolar disorder patients. Neurobiol Dis 2009, 37(3):596-603.

33. Rao JS, Harry GJ, Rapoport SI, Kim HW: Increased excitotoxicity and neuroinflammatory markers in postmortem frontal cortex from bipolar disorder patients. Mol Psychiatry 2010, 15(4):384-392
34. Makar TK, Hungund BL, Cook GA, Kashfi K, Cooper AJ: Lipid metabolism and membrane composition are altered in the brains of type II diabetic mice. J Neurochem 1995, 64(5):2159-2168.

35. Hashimoto M, Kubota Y, Tanaka N, Yamaguchi Y, Fujii Y, Kagota S, Kawakita E, Shido O, Kunitomo M, Shinozuka K: Relationship between plasma and hippocampal lipid peroxidation in obese and hypertensive SHR/NDmcr-cp rats. Clin Exp Pharmacol Physiol 2004, 31(Suppl 2):S62-S64.

36. Sharma J, Turk J, Mancuso DJ, Sims HF, Gross RW, McHowat J: Activation of group VI phospholipase A2 isoforms in cardiac endothelial cells. Am J Physiol Cell Physiol 2011, 300(4):C872-C879.

37. Sharma J, Turk J, McHowat J: Endothelial cell prostaglandin I(2) and platelet-activating factor production are markedly attenuated in the calcium-independent phospholipase A(2)beta knockout mouse. Biochemistry 2010, 49(26):5473-5481.

38. Basselin M, Ramadan E, Igarashi M, Chang L, Chen M, Kraft AD, Harry GJ, Rapoport SI: Imaging upregulated brain arachidonic acid metabolism in HIV-1 transgenic rats. J Cereb Blood Flow Metab 2011, 31(2):486-493.

39. Thirumangalakudi L, Rao HV, Grammas P: Involvement of PGE2 and PGDH but not COX-2 in thrombin-induced cortical neuron apoptosis. Neurosci Lett 2009, 452(2):172-175.

40. Acheson A, Conover JC, Fandl JP, DeChiara TM, Russell M, Thadani A, Squinto SP, Yancopoulos GD, Lindsay RM: A BDNF autocrine loop in adult sensory neurons prevents cell death. Nature 1995, 374(6521):450-453.

41. Stranahan AM, Norman ED, Lee K, Cutler RG, Telljohann RS, Egan JM, Mattson MP: Diet-induced insulin resistance impairs hippocampal synaptic plasticity and cognition in middle-aged rats. Hippocampus 2008, 18(11):1085-1088.

42. Molteni R, Barnard RJ, Ying Z, Roberts CK, Gomez-Pinilla F: A high-fat, refined sugar diet reduces hippocampal brain-derived neurotrophic factor, neuronal plasticity, and learning. Neuroscience 2002, 112(4):803-814

43. Li ZG, Zhang W, Sima AA: Alzheimer-like changes in rat models of spontaneous diabetes. Diabetes 2007, 56(7):1817-1824.

44. Chepulis LM, Starkey NJ, Waas JR, Molan PC: The effects of long-term honey, sucrose or sugar-free diets on memory and anxiety in rats. Physiology \& Behavior 2009, 97(3-4):359-368

45. Mancuso DJ, Sims HF, Yang K, Kiebish MA, Su X, Jenkins CM, Guan S, Moon SH, Pietka T, Nassir F, et al: Genetic ablation of calcium-independent phospholipase A2gamma prevents obesity and insulin resistance during high fat feeding by mitochondrial uncoupling and increased adipocyte fatty acid oxidation. J Biol Chem 2010, 285(47):36495-36510.

46. Han MS, Lim YM, Quan W, Kim JR, Chung KW, Kang M, Kim S, Park SY, Han JS, Cheon HG, et al: Lysophosphatidylcholine as an effector of fatty acidinduced insulin resistance. J Lipid Res 2011, 52(6):1234-1246.

47. Kellom M, Basselin M, Keleshian VL, Chen M, Rapoport SI, Rao JS: Dosedependent changes in neuroinflammatory and arachidonic acid cascade markers with synaptic marker loss in rat lipopolysaccharide infusion model of neuroinflammation. BMC Neurosci 2012, 13(1):50.

48. Kim HW, Chang YC, Chen M, Rapoport SI, Rao JS: Chronic NMDA administration to rats increases brain pro-apoptotic factors while decreasing anti-Apoptotic factors and causes cell death. BMC Neurosci 2009, 10:123.

49. Rao JS, Ertley RN, Rapoport SI, Bazinet RP, Lee HJ: Chronic NMDA administration to rats up-regulates frontal cortex cytosolic phospholipase $A 2$ and its transcription factor, activator protein-2. J Neurochem 2007, 102(6):1918-1927.

50. Pagliassotti MJ, Prach PA, Koppenhafer TA, Pan DA: Changes in insulin action, triglycerides, and lipid composition during sucrose feeding in rats. Am J Physiol 1996, 271(5 Pt 2):R1319-R1326.

51. Pagliassotti MJ, Prach PA: Quantity of sucrose alters the tissue pattern and time course of insulin resistance in young rats. Am J Physiol 1995, 269(3 Pt 2):R641-R646.

52. Chicco A, D'Alessandro ME, Karabatas L, Pastorale C, Basabe JC, Lombardo YB: Muscle lipid metabolism and insulin secretion are altered in insulinresistant rats fed a high sucrose diet. J Nutrition 2003, 133(1):127-133.

53. Sharma S, Zhuang $Y$, Gomez-Pinilla F: High-fat diet transition reduces brain DHA levels associated with altered brain plasticity and behaviour. Sci Rep 2012, 2:431.

54. Hatanpaa K, Isaacs KR, Shirao T, Brady DR, Rapoport SI: Loss of proteins regulating synaptic plasticity in normal aging of the human brain and in Alzheimer disease. J Neuropathol Exp Neurol 1999, 58(6):637-643.

55. Rao JS, Kellom M, Kim HW, Rapoport SI, Reese EA: Neuroinflammation and synaptic loss. Neurochem Res 2012, 37(5):903-910. 
56. Matthews DR, Hosker JP, Rudenski AS, Naylor BA, Treacher DF, Turner RC: Homeostasis model assessment: insulin resistance and beta-cell function from fasting plasma glucose and insulin concentrations in man. Diabetologia 1985, 28(7):412-419.

57. Lin LL, Wartmann M, Lin AY, Knopf JL, Seth A, Davis RJ: CPLA2 is phosphorylated and activated by MAP kinase. Cell 1993, 72(2):269-278.

58. Xing M, Insel PA: Protein kinase C-dependent activation of cytosolic phospholipase A2 and mitogen-activated protein kinase by alpha 1adrenergic receptors in Madin-Darby canine kidney cells. J Clin Invest 1996, 97(5):1302-1310.

59. Deutsch J, Rapoport SI, Purdon AD: Relation between free fatty acid and acyl-CoA concentrations in rat brain following decapitation. Neurochem Res 1997, 22(7):759-765.

60. Karmi A, lozzo P, Viljanen A, Hirvonen J, Fielding BA, Virtanen K, Oikonen V, Kemppainen J, Viljanen T, Guiducci L, et al: Increased brain fatty acid uptake in metabolic syndrome. Diabetes 2010, 59(9):2171-2177.

61. Posey KA, Clegg DJ, Printz RL, Byun J, Morton GJ, Vivekanandan-Giri A, Pennathur S, Baskin DG, Heinecke JW, Woods SC, et al: Hypothalamic proinflammatory lipid accumulation, inflammation, and insulin resistance in rats fed a high-fat diet. Am J Physiol Endocrinol Metab 2009, 296(5):E1003-E1012.

62. Umhau JC, Zhou W, Carson RE, Rapoport SI, Polozova A, Demar J, Hussein $\mathrm{N}$, Bhattacharjee AK, Ma K, Esposito G, et al: Imaging incorporation of circulating docosahexaenoic acid into the human brain using positron emission tomography. J Lipid Res 2009, 50(7):1259-1268.

63. Ramadan E, Rosa AO, Chang L, Chen M, Rapoport SI, Basselin M: Extracellular-derived calcium does not initiate in vivo neurotransmission involving docosahexaenoic acid. J Lipid Res 2010, 51(8):2334-2340.

64. Shonesy BC, Thiruchelvam K, Parameshwaran K, Rahman EA, Karuppagounder SS, Huggins KW, Pinkert CA, Amin R, Dhanasekaran M, Suppiramaniam V: Central insulin resistance and synaptic dysfunction in intracerebroventricular-streptozotocin injected rodents. Neurobiol Aging 2012, 33(2):430 e435-418.

65. Farooqui AA, Farooqui T, Panza F, Frisardi V: Metabolic syndrome as a risk factor for neurological disorders. Cell Mol Life Sci: CMLS 2012, 69(5):741-762.

66. Striggow F, Ehrlich BE: Regulation of intracellular calcium release channel function by arachidonic acid and leukotriene B4. Biochem Biophys Res Commun 1997, 237(2):413-418.

67. Gharib SA, Khalyfa A, Abdelkarim A, Bhushan B, Gozal D: Integrative miRNA-mRNA Profiling of Adipose Tissue Unravels Transcriptional Circuits Induced by Sleep Fragmentation. PLoS One 2012, 7(5):e37669.

68. Kanitz A, Gerber AP: Circuitry of mRNA regulation. Wiley Interdiscip Rev Syst Biol Med 2010, 2(2):245-251.

69. McCall CE, El Gazzar M, Liu T, Vachharajani V, Yoza B: Epigenetics, bioenergetics, and microRNA coordinate gene-specific reprogramming during acute systemic inflammation. J Leukoc Biol 2011, 90(3):439-446.

70. Garrido R, Springer JE, Hennig B, Toborek M: Nicotine attenuates arachidonic acid-induced apoptosis of spinal cord neurons by preventing depletion of neurotrophic factors. J Neurotrauma 2003, 20(11):1201-1213.

71. Toalson P, Ahmed S, Hardy T, Kabinoff G: The Metabolic Syndrome in Patients With Severe Mental IIInesses. Primary care companion to the Journal of clinical psychiatry 2004, 6(4):152-158.

72. Obici S, Feng Z, Arduini A, Conti R, Rossetti L: Inhibition of hypothalamic carnitine palmitoyltransferase-1 decreases food intake and glucose production. Nature medicine 2003, 9(6):756-761.

73. Mera P, Bentebibel A, Lopez-Vinas E, Cordente AG, Gurunathan C, Sebastian D, Vazquez I, Herrero L, Ariza X, Gomez-Puertas P, et al: C75 is converted to C75-CoA in the hypothalamus, where it inhibits carnitine palmitoyltransferase 1 and decreases food intake and body weight. Biochem Pharmacol 2009, 77(6):1084-1095.

74. Farias SE, Basselin M, Chang L, Heidenreich KA, Rapoport SI, Murphy RC: Formation of eicosanoids, E2/D2 isoprostanes, and docosanoids following decapitation-induced ischemia, measured in high-energymicrowaved rat brain. J Lipid Res 2008, 49(9):1990-2000.

75. Reeves PG, Nielsen FH, Fahey GC Jr: AIN-93 purified diets for laboratory rodents: final report of the American Institute of Nutrition ad hoc writing committee on the reformulation of the AIN-76A rodent diet. J Nutrition 1993, 123(11):1939-1951.

76. Igarashi M, Ma K, Chang L, Bell JM, Rapoport SI: Dietary n-3 PUFA deprivation for 15 weeks upregulates elongase and desaturase expression in rat liver but not brain. J Lipid Res 2007, 48(11):2463-2470.

77. Mariotti F, Hermier D, Sarrat C, Magne J, Fenart E, Evrard J, Tome D, Huneau JF: Rapeseed protein inhibits the initiation of insulin resistance by a highsaturated fat, high-sucrose diet in rats. Br J Nutr 2008, 100(5):984-991.

78. Szeto IM, Aziz A, Das PJ, Taha AY, Okubo N, Reza-Lopez S, Giacca A, Anderson $\mathrm{GH}$ : High multivitamin intake by Wistar rats during pregnancy results in increased food intake and components of the metabolic syndrome in male offspring. Am J Physiol Regul Integr Comp Physiol 2008, 295(2):R575-R582.

79. Folch J, Lees M, Sloane Stanley GH: A simple method for the isolation and purification of total lipides from animal tissues. J Biol Chem 1957, 226:497-509.

80. Livak KJ, Schmittgen TD: Analysis of relative gene expression data using real-time quantitative PCR and the 2(-Delta Delta C(T)) Method. Methods 2001, 25(4):402-408.

81. Bradford MM: A rapid and sensitive method for the quantitation of microgram quantities of protein utilizing the principle of protein-dye binding. Anal Biochem 1976, 72:248-254.

82. Radin NS: Extraction of tissue lipids with a solvent of low toxicity. Methods Enzymol 1981, 72:5-7.

doi:10.1186/1471-2202-13-131

Cite this article as: Taha et al:: Upregulated expression of brain enzymatic markers of arachidonic and docosahexaenoic acid metabolism in a rat model of the metabolic syndrome. BMC Neuroscience 2012 13:131.

\section{Submit your next manuscript to BioMed Central and take full advantage of:}

- Convenient online submission

- Thorough peer review

- No space constraints or color figure charges

- Immediate publication on acceptance

- Inclusion in PubMed, CAS, Scopus and Google Scholar

- Research which is freely available for redistribution

Submit your manuscript at www.biomedcentral.com/submit
C) Biomed Central 